
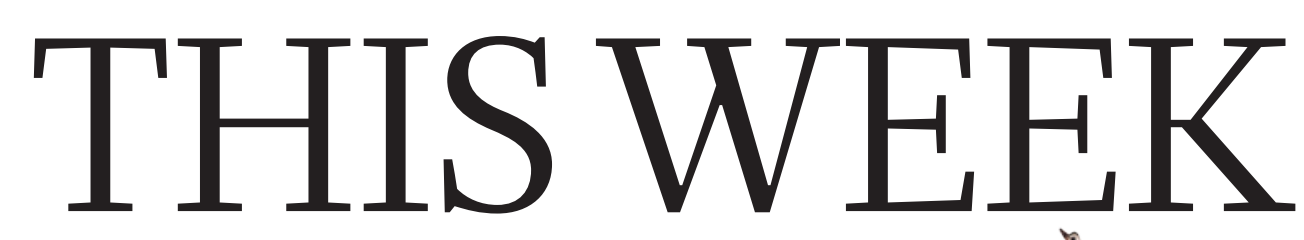

\title{
EDITORIALS
}

FROZEN Antarctica is a distant but not a remote place $\mathbf{p . 3 9 2}$
WORLD VIEW MY former

boss Tim Hunt is

no sexist $\mathbf{p . 3 9 3}$

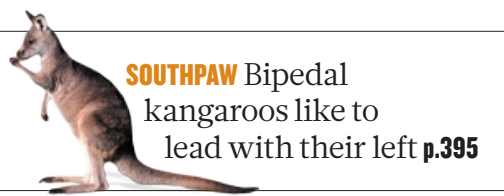

\section{Hope from the Pope}

\section{The Vatican has produced a timely and valuable warning on the threat of climate change that will reach a wide audience.}

$\mathrm{R}$ elations between the Catholic Church and science have long been ambivalent. Famously, it took the Vatican 359 years to formally concede that Earth moves around the Sun: only in 1992 was Galileo Galilei, who proclaimed that fact in 1633, officially 'rehabilitated' by Pope John Paul II.

It is gratifying that Catholic officials have moved on. Pope Francis's much-anticipated encyclical letter on climate and the environment, released last week with great fanfare, is of course pastoral in tone and intent. And yet, the papal letter testifies to the respect and honest understanding that the Argentinian Pope and his cardinals have for science.

"Science is the best tool by which we can listen to the cry of the Earth," Cardinal Peter Turkson, president of the Pontifical Council for Justice and Peace, said on releasing the 192-page letter, drafted in consultation with leading climate experts. While calling on leaders to step up efforts to reduce global greenhouse emissions (which the encyclical acknowledges to be the main cause of warming), the Pope warns in strong language that unabated climate change will cause severe disruptions to ecosystems and human societies. His letter to the world's more than one billion Catholics repeatedly stresses the moral imperative for action on global warming, poverty and overexploitation of natural resources.

With international climate negotiations entering a decisive phase, the Vatican has chosen the right time to weigh in. Combined with a pledge earlier this month from the G7 leading industrialized nations to phase out fossil fuels, hopes are increasing that the next round of global climate negotiations, in Paris in December, might reach a meaningful deal.

Scientists and political leaders in favour of climate action have rightly expressed gratitude and admiration for Pope Francis's brave move. In doing so, President Barack Obama said that the United States must be a leader in efforts to cut carbon pollution and protect the environment. Other nations must follow suit. It will take more than spiritual aid to set the course for a clean-energy future, but the political weight of the Pope's appeal to the moral conscience and reason of millions of people must not be underestimated.

The fact that the Vatican has sided with those who criticize the excesses of capitalism and consumerism - systems that the Pope labels in the encyclical as culprits in the world's ecological crisis - could fuel suspicion in some quarters. But his plea for moderation and sustainability should not be dismissed as naive or utopian. The long-held view that continuous economic growth produces perpetual happiness and wellbeing is increasingly being questioned, including by forward-looking economists and social psychologists. And the financial crisis of recent years has produced ample evidence of the risks of runaway capitalism.

Wisely, Pope Francis has framed the issue of global change along the lines of hope and opportunity, rather than of doom and gloom. Why, he asks, should humankind take the risk of dangerously altering the planet's climate and biosphere when there are viable alternatives?

The papal calls to end poverty and share the world's ecological space in a fair way are objectives that mirror the United Nations' Sustainable

Development Goals, to be released in September. The Pope's letter adds an important facet to the discussion: it is not merely conceivable to secure a sound future for human civilization without relying on coal, oil and gas - it is a prerequisite.

Given the Pope's moral authority and sky-rocketing popularity — not just among Catholics - his words might travel farther than sober scientific reports by bodies such as the Intergovernmental Panel on

"It will take more than spiritual aid to set the course for a cleanenergy future." Climate Change (IPCC). Those tomes tend to brim with jargon and are read by relatively few people. And unlike the IPCC, which sometimes struggles with public outreach, the Catholic Church has a superb means of spreading the word every Sunday. A global campaign that the church plans to run in coming months could step up the urgency for the December climate talks. To build useful momentum, climate policies must be top of the agenda when Pope Francis visits the White House and addresses the UN General Assembly in September.

Meanwhile, within the encyclical are other issues that are important for science. Remarkably, the Pope concedes that intervening with plants and animals is "permissible when it pertains to the necessities of human life". The clause signals a rethink of the Catholic Church's attitude to genetic engineering and animal research. Alas, he remained silent on issues of contraception. With a world population heading towards a possible 10 billion, the importance of family planning is clear. The Vatican has been brave on climate change. If it is serious about the fate of the planet and the welfare of its inhabitants, then it must be braver still on the issue of contraception.

\section{Data overprotection}

\section{Draft European rules governing privacy threaten to hamper medical research.}

$\mathrm{W}$ hen officials at the European Commission proposed new data-protection rules in 2012, the prospects for science looked good. Three years on, that optimism has been replaced by concern. The best that researchers can hope for from the rules now, it seems, is that they do not make things worse. For, as politicians continue to try to protect the individual in a digital world, they risk inflicting major long-term damage on the research environment.

The rules aim to update the 1995 data-protection regulations to reflect the reality of the digital age, in which information about individuals is increasingly being used as a commodity. 